\title{
Air Quality Characteristics in Junior High School Classroom with Natural Ventilation in Pangkep Regency
}

\author{
Nur Mutmainnaha, ${ }^{\mathrm{a},}$, Rosady Mulyadi ${ }^{\mathrm{b}}$, Baharuddin Hamzah ${ }^{\mathrm{c}}$ \\ aDepartment of Architecture Research, Engineering Faculty, Hasanuddin University. Email: mutmainnahn15p@student.unhas.ac.id \\ bepartment of Architecture Research, Engineering Faculty, Hasanuddin University. Email: rosady@unhas.ac.id \\ ${ }^{\mathrm{c}}$ Department of Architecture Research, Engineering Faculty, Hasanuddin University. Email: baharsyah@unhas.ac.id
}

\begin{abstract}
The indoor air quality room has turned out to be a major concern due to its adverse effects on human health. This is related to the level of activity of human spent almost 90 percent of their time indoors. This study aims to identify the characteristics of air quality in classrooms with natural ventilation systems in three different schools, which vary in topography and the surrounding environment, namely coastal areas, lowlands, and mountains. Air quality measurement focuses on carbon monoxide $(\mathrm{CO})$, carbon dioxide $\left(\mathrm{CO}_{2}\right)$ concentration, total dust content, temperature $(T)$, humidity $(R H)$, and airflow velocity. The statistical results showed significantly different $(p<0.05)$ in air quality parameters among those three schools. The $\mathrm{CO}$ and $\mathrm{CO}_{2}$ concentrations in the three schools are below the recommendations required by DOSH and ASHRAE. This clarifies that a well-used natural ventilation system is able to maintain the air quality in the classroom. The measurement of total dust levels was above the threshold required by the Ministry of Health of the Republic of Indonesia No.1405/MENKES/SK/XI/2002. In addition, there was a significant relationship $(p<0.05)$ between air pollutants and meteorological factors such as temperature and air humidity in the classroom. This study found that there was an influence of human activity level and the surrounding environment on the amount of pollutants concentration in the classroom.
\end{abstract}

Keywords: Carbon monoxide $(\mathrm{CO})$, carbon dioxide $\left(\mathrm{CO}_{2}\right)$; indoor air quality; natural ventilation; total dust content

\section{Introduction}

The issue of indoor air quality began to get public attention when a study conducted by EPA in 1989 stated that the impact of air pollution in space is heavier than outdoors. In addition, according to the Green Building Council, Indonesia indoor air pollution is more dangerous 4 times than outdoor pollution, especially if the room does not have a good ventilation system and uses unattended mechanical ventilation.

Humans spend an average of $70 \%-90 \%$ in the room both for work, study, and rest. Whereas in the world of education, students and teaching staff tend to spend at least 6-8 hours/day at school. Therefore, the school must pay attention to and create an atmosphere of a conducive, healthy, and comfortable teaching and learning room, so that the school's mission to educate students is achieved.

In the previous study, it was found that air quality in the classroom can affect students' learning processes both from

*Corresponding author. Tel.: +6281354630436

Jalan Poros Malino km. 6 Bontomarannu

Gowa, Sulawesi Selatan, Indonesia, 92171 concentration and presence [1]. Poor air quality in the classroom has an impact on the health of children in schools such as respiratory problems, irritation/allergies, and others that can reduce students' learning performance [2]. Rooms that have good air circulation can produce good air quality inside. Air circulation is influenced by various factors, one of which is the ventilation system.

In general, educational buildings in Indonesia have relied on air conditioning systems and natural lighting for thermal comfort and air quality. However, the average state school in Indonesia are built on the same standard/prototype, without being based on consideration of local climate conditions and taking into account the comfort of its users, as a result, the existing classrooms are far from comfortable [3]. In addition, air quality is influenced by various factors, including location, various activities, pollutants, and meteorology and topography that affect the spread of pollutants in the air [4-6].

This research was conducted at junior high schools in Pangkep. As we know, there are many factories in Pangkep, such as cement, marble and so on. This has the potential to contribute to air pollution in the environment. 
This study aims to evaluate the air quality in the classroom and compare the air quality of the school according to the surrounding environment including schools in coastal areas, lowland areas, and mountainous regions. This study focuses on the concentration of pollutants of carbon monoxide $(\mathrm{CO})$, carbon dioxide $\left(\mathrm{CO}_{2}\right)$, total dust levels and meteorological parameters (humidity $(R H)$, temperature $(T)$, and airflow velocity.

\section{Method}

This research employs survey and experimental design. The samples involved were public junior high schools (SMPN) in three regions, namely 1 school in the coastal area (SMPN 1 Mandalle), 1 school in the lowland area (SMPN 2 Bungoro), and 1 school in the mountainous area (SMPN 2 Balocci). The school located in coastal areas directly adjacent to provincial highways, the school in the lowlands are in ring 1 of the PT. Semen Tonasa II with distance about \pm 500 meters from Tonasa II Region, while the school in the mountain is bordered by mountains and rice fields.

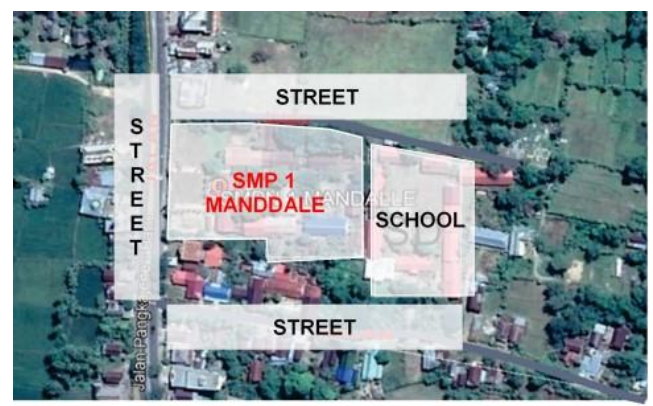

(1)

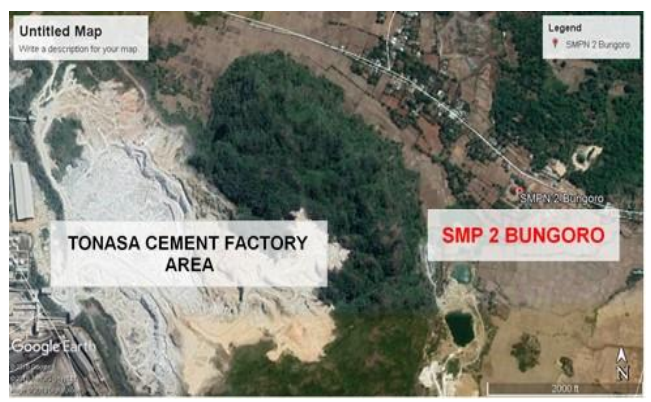

(2)

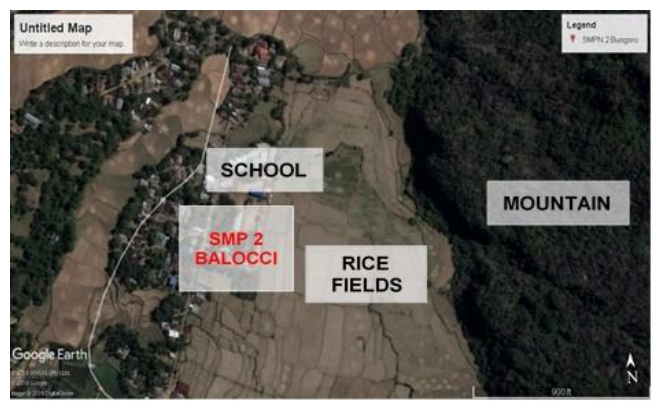

(3)

Figure 1. Samples of Schools in Pangkep: (1) School in Coastal, (2) School in Lowlands, (3) School in Mountain.

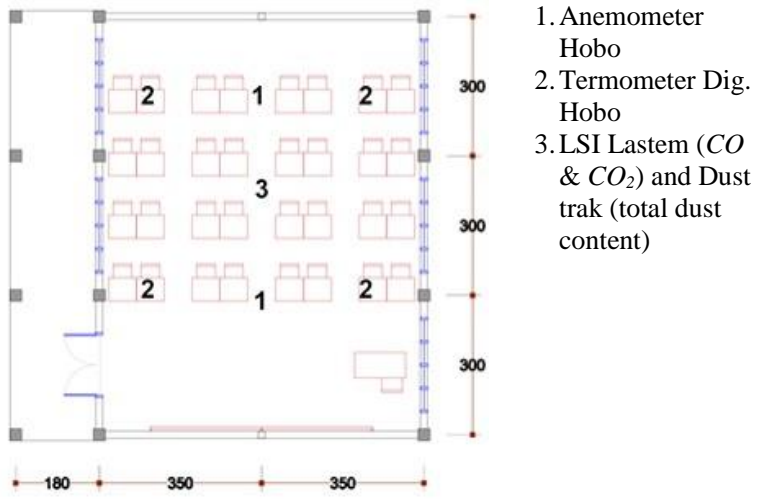

Figure 2. Placement of the measurement spot

Measurements were conducted for three days in each sample location. Measurements of temperature, humidity, $\mathrm{CO}$ and $\mathrm{CO}_{2}$ levels were carried out for six hours a day from 7:30 a.m. to 1:00 p.m. for each sample. Measurement of total dust levels was carried out by the method of instantaneous / grab sampler for 1 day per sample at certain hours, namely at 08.00-9.00; 10:00 11:00 and 12:00 to 13:00. The study was conducted on August 8, 2018 - August 30, 2018. Placement of the measuring instrument refers to Mahyuddin and Awbi [7] which is in the middle of the room above the height of the students' breathing zone in a sitting position.

Quantitative data analyzed with statistical analysis using SPSS. ANOVA analysis with Kruskal Wallis $H$ to determine the significance of differences in air quality values in classrooms at different locations, while the Spearman bivariate correlation test to determine the relationship between pollutants and meteorological parameters in three measurement regions.

\section{Discussion}

\subsection{Classroom occupancy rate}

Classroom size in accordance with the Minister of Education Regulation No. 24 of 2007 is 7 meters $x 9$ meters $\mathrm{x} 3.20$ meters. The number of students in the classroom is around 25-27 people. The density of classrooms with these sizes is $2.33-2.52 \mathrm{~m}^{2} /$ student, higher than the standard/ provision in the Minister of Health Decree No.1429/ MENKES/SK/2006, which is at least $1.75 \mathrm{~m}^{2} /$ student with $3 \mathrm{~m}$ height ceiling.

\subsection{Comparison of classroom air quality in 3 locations (coastal, lowlands, and mountains).}

To compare the classrooms air quality in three measured locations, the F- test using a nonparametric test with Kruskal Wallis $\mathrm{H}$ was employed. The hypothesis of this study is as follows.

- Ho: all three groups/locations have the same average value

- H1: all three groups/locations have different mean values. 
Table 1. F Test- Kruskall Wallis air quality in 3 measured sample locations

\begin{tabular}{lcccccc}
\hline \multicolumn{7}{c}{ Test Statistics $^{\mathbf{a}, \mathbf{b}}$} \\
& Co & $\mathrm{CO} 2$ & $\mathrm{~T}$ & $\mathrm{RH}$ & $\begin{array}{c}\text { Airflo } \\
\mathrm{w}\end{array}$ & $\begin{array}{c}\text { Total } \\
\text { dust } \\
\text { content }\end{array}$ \\
\hline Chi- & 424.50 & 110.13 & 130.01 & 328.01 & 82.248 & 161.54 \\
$\begin{array}{l}\text { Square } \\
\text { df }\end{array}$ & 9 & 6 & 7 & 2 & 2 & 8 \\
$\begin{array}{l}\text { Asym } \\
\text { p. Sig. }\end{array}$ & .000 & .000 & .000 & .000 & .000 & .000 \\
$\begin{array}{l}\text { a. Kruskal Wallis Test } \\
\text { b. Grouping Variable: School }\end{array}$ & & & & & \\
\hline
\end{tabular}

Table 2. result of temperature and humidity measurement

\begin{tabular}{cccc}
\hline school in the & school in the \\
lowland area & coastal area & $\begin{array}{c}\text { school in the } \\
\text { mountainous } \\
\text { area }\end{array}$ \\
\hline \multirow{2}{*}{ Min } & $27.58{ }^{\circ} \mathrm{C}$ & $25.75^{\circ} \mathrm{C}$ & $28.52{ }^{\circ} \mathrm{C}$ \\
& $41.07 \%$ & $51.00 \%$ & $36.84 \%$ \\
\hline \multirow{2}{*}{ Max } & $35.00{ }^{\circ} \mathrm{C}$ & $33.24{ }^{\circ} \mathrm{C}$ & $33.80{ }^{\circ} \mathrm{C}$ \\
& $70.41 \%$ & $84.32 \%$ & $71.57 \%$ \\
\hline \multirow{2}{*}{ Mean } & $32.11{ }^{\circ} \mathrm{C}$ & $29.88{ }^{\circ} \mathrm{C}$ & $31.19{ }^{\circ} \mathrm{C}$ \\
& $56.27 \%$ & $66.06 \%$ & $50.21 \%$ \\
\hline
\end{tabular}

While the conditions used in determining the acceptance criteria for the hypothesis are:

- Ho rejected if $X^{2}$ count $>X^{2}$ table $(p=0.05)$ means that the three groups have different mean values.

- Ho accepted if $X^{2}$ counts $<X^{2}$ table $(p=0.05)$ means that the three groups have the same average value.

Based on the results of the Kruskal Wallis test, the calculated $X^{2}$ values of each variable are different, namely $\mathrm{CO}=424.50, \mathrm{CO}_{2}=110.13$, Temperature $(T)=130.01$, Air Humidity $(R H)=328.01$, Airflow rate $=82.24$ and Total dust levels $=161.548$. The value of $X^{2}$ table $(p=0.05)$ with a free degree of 2 (df2) of 5.99. The calculated $X^{2}$ value greater than the $X^{2}$ table value indicates that all air quality variables ( $\mathrm{CO}, \mathrm{CO}_{2}, \mathrm{~T}, \mathrm{RH}$, air flow, and total dust content) in three locations have significantly different mean values. To find out the comparison of the concentration values of air quality variables in the three measurement locations is explained as follows.

\section{a. Comparison of temperature and humidity values}

From Table 2, we can see the measurement of temperature and humidity in 3 schools. It is recommended for thermal comfort in space is $24^{\circ} \mathrm{C}-27^{\circ} \mathrm{C}$ with air humidity $55 \%-65 \%$ of SNI 6390: 2011. For air temperature at the measurement of 3 schools above the recommended standard. Of the three schools, schools in the lowlands have high-temperature values from 2 schools. The location of the school located in ring 1 of the Semen Tonasa II plant is one factor in the high temperature in the classroom, besides other factors such as classroom openings, student numbers and activities also affect temperature and humidity in the room.
Tablel 3. Air flow velocity result

\begin{tabular}{cccc}
\hline & $\begin{array}{c}\text { school in the } \\
\text { lowland area }\end{array}$ & $\begin{array}{c}\text { school in the } \\
\text { coastal area }\end{array}$ & $\begin{array}{c}\text { school in the } \\
\text { mountainous area }\end{array}$ \\
\hline Min. & $0.05 \mathrm{~m} / \mathrm{s}$ & $0.05 \mathrm{~m} / \mathrm{s}$ & $0.09 \mathrm{~m} / \mathrm{s}$ \\
Max. & $0.71 \mathrm{~m} / \mathrm{s}$ & $0.77 \mathrm{~m} / \mathrm{s}$ & $1.00 \mathrm{~m} / \mathrm{s}$ \\
Mean & $0.17 \mathrm{~m} / \mathrm{s}$ & $0.21 \mathrm{~m} / \mathrm{s}$ & $0.26 \mathrm{~m} / \mathrm{s}$ \\
\hline
\end{tabular}

Table 4. Measurement result of $\mathrm{CO}$ dan $\mathrm{CO}_{2}$

\begin{tabular}{ccccc}
\hline Min & $\mathrm{CO}$ & $\begin{array}{c}\text { school in the } \\
\text { lowland area }\end{array}$ & $\begin{array}{c}\text { school in } \\
\text { the coastal } \\
\text { area }\end{array}$ & $\begin{array}{c}\text { school in the } \\
\text { mountainous } \\
\text { area }\end{array}$ \\
\hline \multirow{4}{*}{ Max } & $\mathrm{CO}_{2}$ & $354.4 \mathrm{ppm}$ & $1.4 \mathrm{ppm}$ & $1.1 \mathrm{ppm}$ \\
& $\mathrm{CO}$ & $1.6 \mathrm{ppm}$ & $2.17 .8 \mathrm{ppm}$ & $362.7 \mathrm{ppm}$ \\
& $\mathrm{CO}_{2}$ & $586.6 \mathrm{ppm}$ & $679.9 \mathrm{ppm}$ & $1.6 \mathrm{ppm}$ \\
Mean & $\mathrm{CO}^{2}$ & $1.2 \mathrm{ppm}$ & $1.8 \mathrm{ppm}$ & $1.39 \mathrm{ppm}$ \\
& $\mathrm{CO}_{2}$ & $438.54 \mathrm{ppm}$ & $475.92 \mathrm{ppm}$ & $409.07 \mathrm{ppm}$ \\
\hline
\end{tabular}

\section{b. Comparison of air flow velocity values}

Table 3 presents comparison of air flow velocity of three measured locations. It is observed that mean velocity increases in the sequence of lowland, costal and mountainous areas.

\section{c. Comparison of $\mathrm{CO}$ dan $\mathrm{CO}_{2}$}

The recommended value of $\mathrm{CO}_{2}$ levels in space should not exceed $1000 \mathrm{ppm}$ per 8 hours and $C O$ levels should not exceed $9 \mathrm{ppm}$ in 8 hours and $35 \mathrm{ppm}$ in 1 hour to be able to feel the air of good quality according to DOSH standards [8] and ASHRAE [9]. From Table 4, the $\mathrm{CO}_{2}$ concentration in 3 schools is below the threshold of the DOSH standard [8] and ASHRAE [9]. In addition, the measurement results of $\mathrm{CO}$ and $\mathrm{CO}_{2}$ in this study belonged to the category "excellent" as the concentration values below $800 \mathrm{ppm}$ and $1.7 \mathrm{ppm}$ as suggested by the Hong Kong EMSD [10].

The value of $\mathrm{CO}$ and $\mathrm{CO}_{2}$ concentrations below the threshold concludes that natural ventilation systems are used well and are able to maintain the air quality in the classroom. As seen in Table 4, schools located in coastal areas precisely in traffic areas have the highest $\mathrm{CO}$ and $\mathrm{CO}_{2}$ concentration values. Besides being due to location factors, the number and activity of students around the measurement points and openings design also causes high values of $\mathrm{CO}$ and $\mathrm{CO}_{2}$ concentrations.

There are not many differences in the value of $\mathrm{CO}_{2}$ among 3 schools because the number of students in each class is almost the same $25-27$ people as recommended by the Indonesian Ministry of National Education. In general, the value of $\mathrm{CO}_{2}$ concentrations in classrooms in each school is significantly higher when the teaching and learning process is compared if the room is in a state of the recess (most students leave the classroom). The results of the measurement of $\mathrm{CO}_{2}$ concentrations in 3 schools in this study were lower than the results of a study conducted by Talarosha [11] in elementary schools that were naturally ventilated in Medan. 
Table 5. Total dust measurement result

\begin{tabular}{cccc}
\hline & $\begin{array}{c}\text { school in the } \\
\text { lowland area }\end{array}$ & $\begin{array}{c}\text { school in the } \\
\text { coastal area }\end{array}$ & $\begin{array}{c}\text { school in the } \\
\text { mountainous area }\end{array}$ \\
\hline Min. & $0.09 \mathrm{mg} / \mathrm{m}^{3}$ & $0.05 \mathrm{mg} / \mathrm{m}^{3}$ & $0.05 \mathrm{mg} / \mathrm{m}^{3}$ \\
Max. & $0.49 \mathrm{mg} / \mathrm{m}^{3}$ & $0.47 \mathrm{mg} / \mathrm{m}^{3}$ & $0.37 \mathrm{mg} / \mathrm{m}^{3}$ \\
Mean & $0.28 \mathrm{mg} / \mathrm{m}^{3}$ & $0.15 \mathrm{mg} / \mathrm{m}^{3}$ & $0.22 \mathrm{mg} / \mathrm{m}^{3}$ \\
\hline
\end{tabular}

\section{d. Comparison of total dust level}

The threshold value of total dust in the air according to the Decree of the Minister of Health of the Republic of Indonesia No.1405/MENKES/SK/XI/2002 concerning the health requirements of office and industrial work environments is $0.15 \mathrm{mg} / \mathrm{m}^{3}$ with air exchange $0.283 \mathrm{~m}^{3} /$ minute/person with airflow rate $0.15-0.25 \mathrm{~m} / \mathrm{s}$.

The measurement results of dust levels in 3 schools in Table 5 showed that 2 schools had total dust content values above the regulatory threshold used, namely schools in lowland areas and schools in the mountains. School locations in the lowlands adjacent to the Tonasa cement factory and schools in the mountains bordered by rice fields are the source of dust in the space. In addition, another factor is the lack of awareness of students to clean the room regularly.

\subsection{Relationship between meteorological parameter variables and the concentration of air quality in the classroom.}

To determine the relationship between meteorological parameters and the concentration of air quality in the classroom, statistical tests are carried out in Table 6 with a "Spearman" bivariate correlation test analysis. The analysis was carried out by correlating between pollutants $\left(\mathrm{CO}, \mathrm{CO}_{2}\right.$, total dust content) and temperature ( $T$ ) parameters, humidity $(R H)$ and airflow velocity in the classrooms at each measured location.

From the tables, the overall relationship between indoor variables studied in all three schools was significant at $p$ $<0.05$. The temperature $(T)$ value had a very strong negative relationship with air humidity $(0.719>r>-0.872)$ in all three schools. In addition, the temperature value in junior high school coastal areas had a strong $r$ value and a significant relationship with several other variables compared to the other 2 schools, where the $r$ value between $T$ and $C O$ is $0.554, \mathrm{~T}$ and $\mathrm{CO}_{2}$ were -0.658 and $\mathrm{T}$ and airflow is 0.217 . This is influenced by the location of the school which is on the side of the road, the activity of students in the classroom, the environment, and surrounding activities.

Temperature values also have a negative relationship with $\mathrm{CO}$ and $\mathrm{CO}_{2}$ concentrations in all three schools, while air humidity had a low positive/weak relationship $(0.289 \geq r$ $\geq 0.545)$ with $\mathrm{CO}$ and $\mathrm{CO}_{2}$ concentrations in 2 schools namely low land area and coast. The negative relationship between temperature and $\mathrm{CO}$ and $\mathrm{CO}_{2}$ concentrations shows a tendency for a relationship between reduced $\mathrm{CO}$ and $\mathrm{CO}_{2}$ concentrations with rising air temperatures in space. This is in line with research conducted by Talarosha [12] and Nagendra \& Harika [13].
Table 6. Correlation of air quality in classrooms

a. Air quality correlation at SMP in the mountains

\begin{tabular}{|c|c|c|c|c|c|c|}
\hline Variable & $T$ & $R H$ & $\begin{array}{c}\text { Air } \\
\text { flow } \\
(\mathrm{m} / \mathrm{s})\end{array}$ & $\mathrm{CO}$ & $\mathrm{CO}_{2}$ & $\begin{array}{c}\text { total } \\
\text { dust } \\
\text { content }\end{array}$ \\
\hline$T$ & 1 & & & & & \\
\hline$R H$ & $-0.872 * *$ & 1 & & & & \\
\hline $\begin{array}{l}\text { Air flow } \\
(\mathrm{m} / \mathrm{s})\end{array}$ & 0.051 & $-0.145 * *$ & 1 & & & \\
\hline $\mathrm{CO}$ & $-0.245^{* *}$ & 0.030 & 0.124 & 1 & & \\
\hline $\mathrm{CO}_{2}$ & $-0.261 * *$ & 0.136 & 0.025 & $0.161 * *$ & 1 & \\
\hline $\begin{array}{l}\text { total dust } \\
\text { content }\end{array}$ & $0.864 * *$ & $-0.842 * *$ & -0.076 & -0.069 & -0.171 & 1 \\
\hline
\end{tabular}

b. Air quality correlation at SMP in the lowland areas

\begin{tabular}{|c|c|c|c|c|c|c|}
\hline Variable & $T$ & $R H$ & $\begin{array}{c}\text { Air } \\
\text { flow } \\
(\mathrm{m} / \mathrm{s})\end{array}$ & $\mathrm{CO}$ & $\mathrm{CO}_{2}$ & $\begin{array}{c}\text { total } \\
\text { dust } \\
\text { content }\end{array}$ \\
\hline$T$ & 1 & & & & & \\
\hline$R H$ & $-0.854 * *$ & 1 & & & & \\
\hline $\begin{array}{l}\text { Air flow } \\
(\mathrm{m} / \mathrm{s})\end{array}$ & 0.036 & -0.001 & 1 & & & \\
\hline $\mathrm{CO}$ & $-0.502 * *$ & $0.545^{* *}$ & 0.043 & 1 & & \\
\hline $\mathrm{CO}_{2}$ & $-0.244 * *$ & $0.289 * *$ & -0.078 & $0.172 * *$ & 1 & \\
\hline $\begin{array}{c}\text { total dust } \\
\text { content }\end{array}$ & $0.832 * *$ & $-0.579 * *$ & 0.017 & -0.074 & -0.090 & 1 \\
\hline
\end{tabular}

c. Air quality correlation at SMP in the coastals

\begin{tabular}{|c|c|c|c|c|c|c|}
\hline Variable & $T$ & $R H$ & $\begin{array}{c}\text { Air } \\
\text { flow } \\
(\mathrm{m} / \mathrm{s}) \\
\end{array}$ & $\mathrm{CO}$ & $\mathrm{CO}_{2}$ & $\begin{array}{c}\text { total } \\
\text { dust } \\
\text { content }\end{array}$ \\
\hline$T$ & 1 & & & & & \\
\hline$R H$ & $-0.719 * *$ & 1 & & & & \\
\hline $\begin{array}{l}\text { Air flow } \\
(\mathrm{m} / \mathrm{s})\end{array}$ & $-0.217 * *$ & -0.062 & 1 & & & \\
\hline $\mathrm{CO}$ & $-0.554 * *$ & $0.353 * *$ & -0.015 & 1 & & \\
\hline $\mathrm{CO}_{2}$ & $-0.658^{* *}$ & $0.322 * *$ & 0.354 & $0.280 * *$ & 1 & \\
\hline $\begin{array}{c}\text { total dust } \\
\text { content }\end{array}$ & 0.103 & $0.335^{* *}$ & -0.184 & 0.056 & -0.155 & 1 \\
\hline
\end{tabular}

**. Correlation is significant at the 0.05 level (1-tailed)

In addition, there was a low/weak positive relationship between $\mathrm{CO}$ concentration values and $\mathrm{CO}_{2}$ concentration values $(0.161 \geq r \geq 0.280)$ in measurements in three schools. The velocity of airflow has no relationship with $\mathrm{CO}$ and $\mathrm{CO}_{2}$ pollutants. This is because the velocity of airflow in three schools is very weak below $0.25 \mathrm{~m} / \mathrm{s}$.

The concentration of the total dust level has a significant relationship with temperature and humidity. A very strong positive relationship found between total dust level and temperature $(0.822 \geq r \geq 0.864)$ in the lowland junior high school and lowland area. This shows that the higher the air temperature in the room, the greater the concentration of total dust. This is consistent with previous relevant research such as in India [14] which has seasonal variations and meteorological conditions similar to Indonesia. The positive correlation of air temperature with total dust concentration can occur because of the increasing air temperature, the emitted dust becomes lighter, so it settles to the ground longer. The result can be crashed and inhaled easily by receptors. 
In contrast to temperature, air humidity has a very strong negative relationship with total dust content $(-0.57 \geq r \geq-$ 0.84 ) in the lowland area and junior high school areas. This is in accordance with previous relevant research which states a negative correlation between air humidity and total dust concentration $[14,15]$. In general, high air humidity results in increasingly heavy dust and accelerates the deposition of dust to the surface of the soil thereby reducing dust emissions that are exposed to a human.

\section{Conclusions}

The results of this study show significant differences in air quality parameters in the classroom at 3 different schools. The measurement results of $\mathrm{CO}$ and $\mathrm{CO}_{2}$ concentrations indicate that the location of schools in the coastal near the traffic area has the highest $\mathrm{CO}$ and $\mathrm{CO}_{2}$ concentration values from the other 2 schools. Whereas the location of the school in ring 1 of the industrial area of Semen Tonasa factory shows a high total dust content of $0.283 \mathrm{mg} / \mathrm{m}^{3}$ above the regulatory threshold stipulated by the Decree of the Minister of Health of the Republic of Indonesia No.1405/ MENKES/SK/XI/2002 which is $0,15 \mathrm{mg} / \mathrm{m}^{3}$.

Measurements of $\mathrm{CO}$ and $\mathrm{CO}_{2}$ concentrations in classrooms are below the threshold of concentration values set by DOSH and ASHRAE. This indicates that the natural ventilation system is used well and is able to maintain the air quality in the classroom. In addition, the result of this study indicates a tendency for a relationship between the reduction of $\mathrm{CO}$ and $\mathrm{CO}_{2}$ concentrations and the increasing air temperatures in the classroom. While humidity has a positive relationship with the concentration of $\mathrm{CO}$ and $\mathrm{CO}_{2}$, which means that the higher the humidity in the room indicates the higher the concentration of $\mathrm{CO}$ and $\mathrm{CO}_{2}$ in space. Meanwhile, the concentration of the total dust level has a significant relationship with temperature and humidity. This shows that the higher the air temperature in the room, the greater the concentration of total dust. In contrast to temperature, air humidity has a very strong negative relationship with total dust levels.

\section{Reference}

[1] Mendell, M.J., \& Heath, G.A. 2004. Do Indoor Environments in School Influence Student Performance? A Critical Review of The Literature. Indoor Air, 15(1), pp.27-52.

[2] Mendell, M.J. 2007. Indoor Residential Chemical Emissions as Risk Factors for Respiratory and Allergic Effects in Children: A Review. Indoor Air Journal, 17, pp.259-277.

[3] Baharuddin, Mulyadi, R., Amin, S. 2016. Thermal Comfort Analysis of Elementary School Classrooms in Makassar City - Case Study of Toddopuli Elementary Primary School. Prosiding Temu Ilmiah IPLBI. [in Bahasa]

[4] EPA. 2013. Technology Transfer Network: National Ambient Air Quality Standards (Online), (http://www.epa.gov/ttn/naaqs/, accessed 22 Maret 2018).

[5] SM for European Local Ports. 2010. Pollution Part 1 of 2 Overview.

[6] British Columbia Air Quality, 2016. Factors Affecting Air Quality. (Online), (http://www.bcairquality.ca/101/air-quality-factors.html, accessed 3 April 2018).

[7] Mahyuddin, Norhayati dan Awbi, H.B. 2012. A Review of $\mathrm{CO}_{2}$ Measurement Procedures in Ventilation Research. International Journal of Ventilation: ISSN 1473-3315.

[8] DOSH. 2010. Industry Code of Practice On Indoor Air Quality Malaysia: Department of Occupational Safety and Health (DOSH), Ministry of Human Resources.

[9] ASHRAE. 2004. ASHRAE Standard 62.1-2004: Ventilation and Acceptable Indoor Air Quality. Atlanta, Georgia: American Society of Heating, Refrigerating and Air-Conditioning Engineers, Inc.

[10] EMSD. 2003. Guidance Notes for the Management of Indoor Air Quality in Offices and Public Places. Hong Kong: Electrical and Mechanical Services Department (EMSD), The Government of the Hong Kong Special Administrative Region, Indoor Air Quality Management Group.

[11] Talarosha, B. 2016. CO2 Concentration in Classrooms with Natural Ventilation System, A Preliminary Study. Prosiding Temu Ilmiah IPLB, 099-0104. [in Bahasa]

[12] Talarosha, B. 2015. Building Adaptation to Thermal Comfort and Its Impact on Air Quality in the Classroom, A Preliminary Study. Proceeding of TAU Conference: Mitigating and Adapting Built Environments for Climate Change in The Tropics. School of Architecture, Tanri Abeng University, Jakarta, Indonesia, 30-31 March 2015. [in Bahasa]

[13] Nagendra, S.M \& Harika, S.P. 2010. Indoor air quality assessment in a school building in Chennai City, India. WIT Transactions on Ecology and the Environment, Vol 136.

[14] Sivaramasundaram, K., \& Muthusubramanian, P. (2010). A preliminary assessment of $P M 10$ and TSP concentrations in Tuticorin, India. Air Qual Atmos Health 3, 95-102.

[15] Monn, C., Braendli, O., Schaeppi, G., Schindler, C., AckermanLiebrich, U., Leuenberger, P., et al. (1995). Particulate Matter $<10$ (PM10) and Total Suspended Particulates (TSP) in urban, rural and alpine air in Switzerland. Atmospheric Environment Vol. 29, No 19,2565-2573. 